\title{
Mammals of the Natural National Park Selva de Florencia, Caldas, Colombia
}

\author{
Héctor E. Ramírez-Chaves ${ }^{1 *}$, Daniela Velásquez-Guarín², Juan D. Ocampo-Velásquez ${ }^{3}$, Ingrith Yuliany Mejía-Fontecha², Amilvia Acosta ${ }^{4}$, Javier E. \\ Colmenares-Pinzón 5 , John Harold Castaño ${ }^{6}$, and Néstor Roncancio Duque ${ }^{7}$ \\ ${ }^{1}$ Departamento de Ciencias Biológicas, Facultad de Ciencias Exactas y Naturales, Universidad de Caldas, y Centro de Museos, \\ Museo de Historia Natural, Universidad de Caldas, Manizales, Colombia. Calle 65 No 26-10, Manizales. Caldas, Colombia. Email: \\ hector.ramirez@ucaldas.edu.co (HER-C). \\ ${ }^{2}$ Grupo de Investigación GEBIOME, Facultad de Ciencias Exactas y Naturales y Museo de Historia Natural, Universidad de Cal- \\ das, Manizales, Colombia. Calle 65 No 26-10, Manizales. Caldas, Colombia. Email: daniela.bio202830@gmail.com (DV-G) and \\ ingrith1896@gmail.com (IYM-F). \\ ${ }^{3}$ Centro de Museos, Museo de Historia Natural, Universidad de Caldas, Manizales, Colombia. Calle 65 No 26-10, Manizales. Caldas, \\ Colombia. Email: jdavidoca@gmail.com (JDO-V) \\ ${ }^{4}$ Profesional PNN Selva de Florencia, Parques Nacionales Naturales de Colombia. Carrera 9 No 2-30, Corregimiento de Florencia, \\ Samaná. Caldas, Colombia. Email: amilviaac@yahoo.es (AA). \\ ${ }^{5}$ Grupo de Estudios en Biodiversidad, Escuela de Biología, Universidad Industrial de Santander, Bucaramanga, Santander, Colom- \\ bia. Carrera 27 No 9, Bucaramanga. Santander, Colombia. Email: javiercolmenaresbiologo@gmail.com (JEC-P). \\ ${ }^{6}$ Grupo de investigación en Biología de la Conservación y Biotecnología, Corporación Universitaria de Santa Rosa de Cabal. Santa \\ Rosa de Cabal, Colombia. Email:john.castano@unisarc.edu.co (JHC). \\ ${ }^{7}$ Asesor en Biología de la Conservación de la Dirección Territorial Andes Occidentales de Parques Nacionales Naturales. Carrera 42 \\ No 47-21, int. 202, Medellín. Antioquia, Colombia. Email: nroncanciod@gmail.com (NRD). \\ ${ }^{*}$ Corresponding author
}

The Department of Caldas, Central Andes of Colombia, has two National Natural Parks protecting strategic Andean ecosystems. However, the available information on mammals in these protected areas has not been compiled or updated recently. Here, we present an updated inventory of the mammals present in the Selva de Florencia National Natural Park. To construct the inventory, we used historical (museum vouchers) and recent records obtained during field activities over the last 20 years. We used several trapping methods including Sherman and Tomahawk traps, mist nets, and camera traps. We documented 81 mammal species belonging to nine orders, 25 families and 59 genera. Bats (Chiroptera: 30 spp.), rodents (Rodentia: 17 spp.), and carnivores (Carnivora: 13 spp.) were the most diverse groups, representing $73.2 \%$ of recorded species. We also recorded orders such as Didelphimorphia (8 species), Primates (5), Pilosa (3), Artiodactyla (2), Cingulata (2), and Eulipotyphla (1). Also, we recorded two endemic species (Marmosops chucha and Cryptotis colombianus) and two new species for the Department of Caldas (Bassaricyon neblina and Heteromys aff. anomalus). These species constitute elements of the Andean region and the Nor-Andean and Chocó-Magdalena biogeographic provinces. We highlight the presence of four endangered primates (Aotus lemurinus, Ateles hybridus, Cebus versicolor, and Saguinus leucopus), two of which are endemic to Colombia: S. leucopus and C. versicolor. This work is the baseline to update the management plan of the protected area, from the review of its conservation targets, the definition of the specific management goals, to its effective monitoring.

El departamento de Caldas, Andes Centrales de Colombia, posee dos Parques Nacionales Naturales, que protegen ecosistemas estratégicos de la zona andina. Sin embargo, la información disponible sobre los mamíferos de estas áreas protegidas no ha sido compilada ni actualizada recientemente. Aquí presentamos un inventario actualizado de los mamíferos presentes en el Parque Nacional Natural Selva de Florencia. Para construir el inventario empleamos registros históricos (especímenes en museos) y registros recientes obtenidos en campo en los últimos 20 años. Empleamos varios métodos de trampeos que incluyen trampas Sherman y Tomahawk, redes de niebla, y trampas cámara. Registramos 81 especies de mamíferos pertenecientes a nueve órdenes, 25 familias y 59 géneros. Los murciélagos (Chiroptera: 30 spp.), roedores (Rodentia: 17 spp.) y carnívoros (Carnivora: 13 spp.) representan el $73.2 \%$ de las especies registradas. Otros órdenes registrados son Didelphimorphia (8 especies), Primates (5), Pilosa (3), Cingulata (2), Artiodactyla (2) y Eulipotyphla (1). Además, registramos dos especies endémicas (Marmosops chucha y Cryptotis colombianus) y dos nuevas especies para el departamento de Caldas (Bassaricyon neblina y Heteromys aff. anomalus). Las especies registradas constituyen elementos de la región andina y de las provincias biogeográficas Norandina y Chocó-Magdalena. Destacamos la presencia de cuatro especies de primates amenazadas (Aotus lemurinus, Ateles hybridus, Cebus versicolor y Saguinus leucopus), de las cuales dos son endémicas de Colombia: S. leucopus y C. versicolor. Este trabajo es la base para la actualización del plan de manejo del área protegida desde la revisión de sus valores objeto de conservación, la definición de objetivos específicos de manejo hasta su monitoreo efectivo.

Keywords: Mist nets; monitoring; photo-trapping; Sherman and Tomahawk traps.

(c) 2021 Asociación Mexicana de Mastozoología, www.mastozoologiamexicana.org 


\section{Introduction}

The research efforts on mammals of Colombia have increased in recent years, and currently the country ranks sixth in number of species on a global scale (Ramírez-Chaves et al. 2016; 2018). In the last 20 years, almost 100 mammal species have been added to the checklist of mammals of the country (see Alberico et al. 2000; Ramírez-Chaves et al. 2020a). This trend has been driven in part by the increase of taxonomic reviews and updates on South American mammals (Gardner 2008; Patton et al. 2015), by the participation of public and private institutions of Colombia, and by the exploration of previously inaccessible areas (Solari et al. 2013). Despite the significant advances made on various research topics, there are still knowledge gaps related to the taxonomy and systematics of several groups, and the ecology and conservation of endemic and endangered species for some regions across the country (see Solari et al. 2013; Noguera-Urbano et al. 2019).

The information gaps are particularly accentuated in protected areas of the country, as most of them lack complete faunal inventories despite mammals being key elements for research and conservation (Roncancio-Duque and Vélez-Vanegas 2019). Mammal's inventories in protected areas have increased in the last decade, especially in large areas such as National Natural Parks (e. g., Mantilla-Meluk et al. 2018). In general, there is available information for Natural Parks located in the Amazon region (e. g., Polanco-Ochoa et al. 2000; Mantilla-Meluk et al. 2018), and specific works on charismatic large mammals such as the cougar (Puma concolor) and the Andean bear (Tremarctos ornatus) in the Andean region of Colombia (e.g., Hernández-Guzmán et al. 2011; Cáceres-Martínez et al. 2020).

At the regional level, the Department of Caldas, located in the Andean region of the country (eastern slope of the Western Cordillera and both slopes of the Central Cordillera), 167 mammal species have been registered (Castaño Salazar 2012; Ramírez-Chaves et al. 2020b). This number includes limited information on records in protected areas like the National Natural Park (NNP) Selva de Florencia, and NNP Los Nevados (Castaño et al. 2003). For example, in the NNP Selva de Florencia, which protects Andean and subAndean ecosystems, around 40 species of mammals have been recorded (Castaño et al. 2003; Roncancio Duque 2012; Acosta Castañeda et al. 2014). This number is likely underestimated, and updated evaluations plus field validations are needed to contribute to the protection of these species and the ecosystems where they are found.

Here, we present the available information on the mammals that inhabit the NNP Selva de Florencia, Central Andes of Colombia. We aim to provide a taxonomic list of mammal species found in the study area and notes on natural history, the methods employed to register them, the localities, elevations, and number of records. This information will serve as baseline for the future research and monitoring plans, as well as to focus more cost-effectively the con- servation efforts of the mammals of this protected area and the landscape in which it is immersed.

\section{Materials and methods}

Study area. The NNP Selva de Florencia is located on the eastern slope of the Central Cordillera, in the municipalities of Pensilvania and Samaná, east of the Department of Caldas, Colombia. The NNP comprises 10,019 ha with an altitudinal gradient between 850 and 2,400 $\mathrm{m}$, and an average annual rainfall of $6,270 \mathrm{~mm}$. This area includes the last Andean rainforest remnants of the current Colombian Coffee Region (Paiba-Alzate et al. 2010), that are part of the Magdalena River Basin (Gómez et al. 2020), and the Magdalena-Urabá Moist Forests and the Magdalena Valley Montane Forests ecoregions (Olson et al. 2001). We sampled localities near the Hondo and San Antonio river basins, and the sectors of the Las Mercedes, Chupaderos I and La Selva microbasins (Figure 1, Table 1).

Data collection. To assess the diversity of mammals in the study area, we conducted sampling efforts in four periods across 2000 and 2018 years: A) October and November 2000. B) April 2001. C) October 2017, and D) February and April 2018. In addition, we implemented 26 sampling points where 30 camera traps (sampling effort: 9,540 camera-days) were randomly located between March 2017 and August 2018. To have a broad taxonomic coverage,

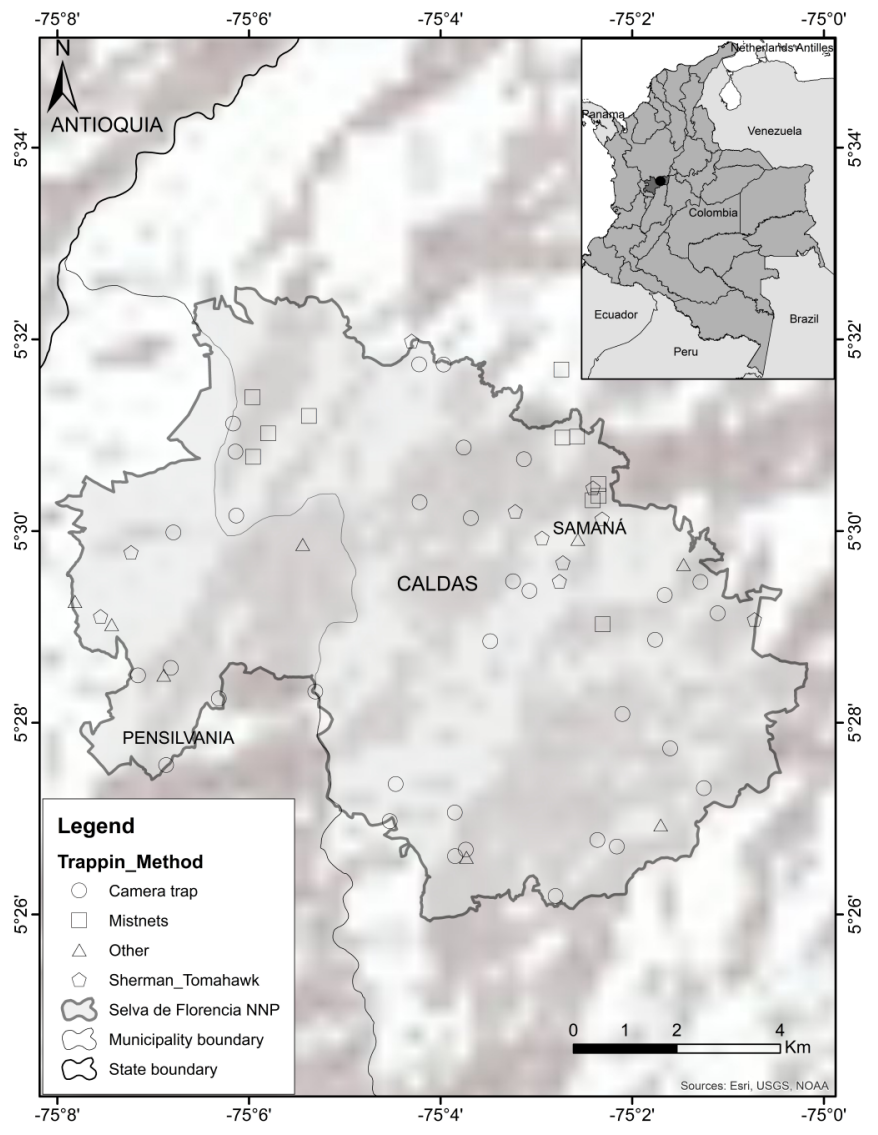

Figure 1. Study area at the Selva de Florencia National Natural Park, Central Andes of the Department of Caldas, Colombia. 
we implemented several trapping methods, including Sherman and Tomahawk ${ }^{\circledR}$ traps for small non-flying mammals, and mist nets for bats, for 64 effective days. The traps installed were baited with roasted and ground peanuts with bacon and salt, in addition to banana or with canned sardines, chicken bones and a mixture of rolled oats, bananas, banana or vanilla essences, and peanut butter (e. g., Voss and Emmons 1996). For capturing bats, five mist nets $(12 \mathrm{~m}$ long $\times 6 \mathrm{~m}$ wide) were installed in four sampling points, between 18:00 and 23:00 hours. To complement the information, we included incidental captures, observations in the field, search for tracks and occasional interviews with park rangers and inhabitants near the NNP Selva de Florencia. In addition, we reviewed vouchers from the NNP Selva de Florencia or its surroundings deposited at the mammal collection of the Natural History Museum of the University of Caldas (MHN-UCa), Manizales, the Instituto Alexander von Humboldt (IAvH), Villa de Leyva, Colombia, and the Field Museum of Natural History (FMNH), Chicago, USA.

We collected vouchers for taxonomic determination in the laboratory, and prepared them as skin and skull, or in fluid (alcohol) with tissues preserved at $96 \%$ ethanol. All the collected specimens were deposited at the MHN-UCa mammal collection (see Ramírez-Chaves et al. 2020b). We took cranial and external measurements following to Simmons and Voss (1998) and Voss et al. (2001). Measurements included for selected specimens (Appendix 1): length of head-and-body (HBL); length of tail (LT); length of hindfoot $(\mathrm{HF})$; length of ear (LE); weight (Wt) in grams (g); greatest length of skull (GLS); condylobasal length (CBL); braincase breadth (BB); maxillary toothrow (MTR); molar length (LM); palatal breadth (PB); palatal length (PL); nasal breadth (NB); Least interorbital breadth (LIB); least postorbital breadth (LPB); zygomatic breadth (ZB); breadth of the zygomatic plate (BZP); rostral breadth (BR); length of diastema (LD); breadth of the first maxillary molar (BM1); length of one incisive foramen (LIF); breadth across both incisive foramina (BIF); interparietal breadth (IPB). For bats we also took the forearm length (FL); condylocanine length $(\mathrm{CCL})$; condyloincisive length (CIL); lacrimal breadth (LB); mastoid breadth (MB); breadth across canines (BC-C), and width across upper molars (BM-M). Taxonomic identification was done using specialized literature and taxonomic keys mainly for marsupials (Gardner 2008; Voss et al. 2018, 2020; Giarla and Voss 2020), bats (Gardner 2008; Díaz et al. 2016), rodents (Patton et al. 2015), and carnivores (Suárez-Castro and Ramírez-Chaves 2015). For marsupials, we include one species as Marmosa sp. which is morphologically similar to M. meridae but a molecular confirmation is needed.

As additional support for taxonomic identification of some rodents collected between 2017 and 2018, we implemented a Cytb-based (Cytochrome B) molecular approach. This marker has been traditionally used for studying mammalian alpha-taxonomy because of its strength to detect cryptic diversity, especially in widely distributed and morphologically homogeneous taxa. Thus, species selected for Cytb characterization have broad geographic ranges or have been pointed out as including undocumented taxonomic variation (Patton et al. 2015): Coendou quichua, Neacomys tenuipes, Heteromys aff. anomalus, and Sigmodontomys alfari. DNA was extracted from fresh tissues of these species with a GeneJet Genomic DNA Purification Kit (Thermo Fisher Scientific), following the manufacturer's instructions. Resulting sequences were verified to represent endogenous DNA of Coendou, Neacomys, Heteromys, and Sigmodontomys by performing independent searches with the Basic Alignment Search Tool (BLAST; Altschul et al. 1990). Matches with identities above $95 \%$ were considered as good candidate species to our samples, according to the genetic species concept (Bradley and Baker 2001). We generated a total of six Cytb sequences: a) One 1,140 base pairs sequence from Coendou quichua (MT822488). b) Two sequences of $688 \mathrm{bp}$ and $703 \mathrm{bp}$ of Heteromys aff. anomalus (Acr1 and Acr2, respectively). c) Three sequences of 872-775 bp sequence from the specimens of Neacomys tenuipes (MT536169-MT536171). d) One 866 bp sequence from Sigmodontomys alfari. We assessed potential cryptic diversity with a close comparison of our sequences with all the sequences of N. tenuipes, H. anomalus, H. australis, and S. alfari, available in GenBank. Finally, the conservation status of the species, especially endemic and threatened, was evaluated with the context of current legislation (MADS 2017), and the International Union for the Conservation of Nature (IUCN 2019). For the endemic species, we include the ecoregions where they inhabit (sensu Olson et al. 2001).

\section{Results}

We recorded a total of 81 mammal species at the NNP Selva de Florencia. The mammals registered belong to 9 orders, 25 families and 59 genera (Table 1). Bats (Chiroptera: 30 spp.), rodents (Rodentia: 17 spp.), and carnivores (Carnivora: 13 spp.) represent $71.4 \%$ of the recorded species. Other orders registered are Didelphimorphia (8 spp.), Primates (5 spp.), Pilosa (3 spp.), Artiodactyla (2 spp.), Cingulata (2 spp.), and Eulipotyphla (1 spp.). We recorded 43 species during 2000 and 2001, and 34 during 2017 and 2018 (Figure 1). Using trapping methods, we captured 330 specimens of bats (mist nets), 24 rodents (Sherman), and 4 marsupials (Tomahawk; Figure 2). The taxa recorded by camera traps include six orders (Didelphimorphia, Cingulata, Pilosa, Carnivora, Artiodactyla and Rodentia) and 16 species (Figure 3). In addition, we recorded 28 species through manual captures, observations, and other indirect records.

Didelphimorphia. We recorded a total of eight species of seven genera in the study area (Table 2), using Tomahawk traps (four species) and direct observations (one species). The review of collections contributed with three additional species (Table 2). In camera traps, only four records of Didelphis marsupialis were obtained in August and December 2017, in two localities at elevations of 1,078 and 1,571 m, respectively. We highlight the presence two species of the genus Marmosa (Marmosa sp., and the short-furred woolly 
Table 1. Sampled localities and dates (day, month, year) at the Selva de Florencia National Natural Park, Department of Caldas, Central Andes of Colombia

\begin{tabular}{|c|c|c|c|c|c|}
\hline & Code / Locality & Latitude & Longitude & Elevation (masl) & Date \\
\hline \multicolumn{6}{|c|}{ Municipality of Pensilvania, “Corregimiento” Pueblo Nuevo } \\
\hline 1 & Vereda El Paraíso & $5^{\circ} 29^{\prime} 51.7^{\prime \prime} \mathrm{N}$ & $-75^{\circ} 05^{\prime} 26.3^{\prime \prime} \mathrm{W}$ & 2,224 & 19.03.2019 \\
\hline \multirow[t]{3}{*}{2} & Vereda Las Colonias & $5^{\circ} 29^{\prime} 06.6^{\prime \prime} \mathrm{N}$ & $-75^{\circ} 07^{\prime} 32.9^{\prime \prime} \mathrm{W}$ & 1,733 & 26.10.2015 \\
\hline & Vereda Las Colonias & $5^{\circ} 29^{\prime} 16.0^{\prime \prime} \mathrm{N}$ & $-75^{\circ} 07^{\prime} 48.9^{\prime \prime} \mathrm{W}$ & 1,530 & 26.10.2015 \\
\hline & Vereda Las Colonias & $5^{\circ} 29^{\prime} 01.5^{\prime \prime} \mathrm{N}$ & $-75^{\circ} 07^{\prime} 25.9^{\prime \prime} \mathrm{W}$ & 1,752 & 26.10 .2015 \\
\hline \multirow[t]{3}{*}{3} & Vereda Buenos Aires, sector Montebello, predio Segundo Zuluaga & $5^{\circ} 28^{\prime} 29.9^{\prime \prime} \mathrm{N}$ & $-75^{\circ} 06^{\prime} 53.3^{\prime \prime} \mathrm{W}$ & 2,088 & March-July 2016 \\
\hline & Buenos Aires, sector Montebello & $5^{\circ} 28^{\prime} 34.4^{\prime \prime} \mathrm{N}$ & $-75^{\circ} 06^{\prime} 48.9^{\prime \prime} \mathrm{W}$ & 2,082 & $26.10 .2016-05.12 .2016$ \\
\hline & Buenos Aires, sector Montebello & $5^{\circ} 28^{\prime} 29.7^{\prime \prime} \mathrm{N}$ & $-75^{\circ} 07^{\prime} 09.4^{\prime \prime} \mathrm{W}$ & 2,167 & $26.10 .2016-05.12 .2016$ \\
\hline 4 & Vereda El Silencio & $5^{\circ} 29^{\prime} 46.7^{\prime \prime} \mathrm{N}$ & $-75^{\circ} 07^{\prime} 13.8^{\prime \prime} \mathrm{W}$ & 1,620 & Feb.-May 2014 \\
\hline \multirow[t]{3}{*}{5} & Vereda Miraflores, sector Cuchilla de Miraflores & $5^{\circ} 30^{\prime} 09.7^{\prime \prime} \mathrm{N}$ & $-75^{\circ} 06^{\prime} 07.9^{\prime \prime} \mathrm{W}$ & 1,980 & 26.07.2016 - 28.09.2016 \\
\hline & Vereda Miraflores, sector Cuchilla de Miraflores & $5^{\circ} 30^{\prime} 49.8^{\prime \prime} \mathrm{N}$ & $-75^{\circ} 06^{\prime} 08.4^{\prime \prime} \mathrm{W}$ & 1,986 & $28.10 .2016-06.12 .2016$ \\
\hline & Vereda Miraflores, Reserva La Italia & $5^{\circ} 31^{\prime} 07.3^{\prime \prime} \mathrm{N}$ & $-75^{\circ} 06^{\prime} 09.9^{\prime \prime} \mathrm{W}$ & 1,951 & $12.07 .2018-30.08 .2018$ \\
\hline \multirow[t]{2}{*}{6} & Vereda San Francisco, sector Boquerón & $5^{\circ} 27^{\prime} 33.6^{\prime \prime} \mathrm{N}$ & $-75^{\circ} 06^{\prime} 51.8^{\prime \prime} \mathrm{W}$ & 1,920 & $08.11 .2017-11.12 .2017$ \\
\hline & Vereda San Francisco, sector Boquerón & $5^{\circ} 28^{\prime} 15.2^{\prime \prime} \mathrm{N}$ & $-75^{\circ} 06^{\prime} 18.8^{\prime \prime} \mathrm{W}$ & 1,999 & $02.05 .2018-05.06 .2018$ \\
\hline 7 & Vereda Las Mercedes & $5^{\circ} 29^{\prime} 59.2^{\prime \prime} \mathrm{N}$ & $-75^{\circ} 06^{\prime} 47.3^{\prime \prime} \mathrm{W}$ & 1,818 & $11.04 .2018-15.05 .2018$ \\
\hline \multicolumn{6}{|c|}{ Municipality of Samaná, “Corregimiento” de Florencia } \\
\hline \multirow[t]{6}{*}{8} & Vereda San Antonio & $5^{\circ} 30^{\prime} 22^{\prime \prime} \mathrm{N}$ & $-75^{\circ} 02^{\prime} 21.0^{\prime \prime} \mathrm{W}$ & 1,300 & 07.10 .2017 \\
\hline & Vereda San Antonio, Microcuenca Las Mercedes & $5^{\circ} 30^{\prime} 27.1^{\prime \prime} \mathrm{N}$ & $-75^{\circ} 02^{\prime} 24.5^{\prime \prime} \mathrm{W}$ & 1,227 & \\
\hline & Microcuenca Las Mercedes & $5^{\circ} 30^{\prime} 07.7^{\prime \prime} \mathrm{N}$ & $-75^{\circ} 02^{\prime} 18.8^{\prime \prime} \mathrm{W}$ & 1,066 & \\
\hline & Microcuenca Las Mercedes & $5^{\circ} 30^{\prime} 29.5^{\prime \prime} \mathrm{N}$ & $-75^{\circ} 02^{\prime} 21.2^{\prime \prime} \mathrm{W}$ & 1,275 & \\
\hline & Microcuenca Las Mercedes & $5^{\circ} 30^{\prime} 19.3^{\prime \prime} \mathrm{N}$ & $-75^{\circ} 02^{\prime} 24.7^{\prime \prime} \mathrm{W}$ & 1,259 & 20.02.2018-24.02.2018 \\
\hline & Sector El Hoyo, cráter volcán El Escondido & $5^{\circ} 30^{\prime} 58.5^{\prime \prime} \mathrm{N}$ & $-75^{\circ} 02^{\prime} 43.7^{\prime \prime} \mathrm{W}$ & 2,224 & 27.08.2018 \\
\hline \multirow[t]{6}{*}{9} & Vereda La Cabaña & $5^{\circ} 31^{\prime} 41.4^{\prime \prime} \mathrm{N}$ & $-75^{\circ} 02^{\prime} 44.3^{\prime \prime} \mathrm{W}$ & 1,200 & 05.01 .2001 \\
\hline & Vereda La Cabaña & $5^{\circ} 29^{\prime} 28.2^{\prime \prime} \mathrm{N}$ & $-75^{\circ} 01^{\prime} 17.3^{\prime \prime} \mathrm{W}$ & 1,382 & 29.01.2018 - 08.03.2018 \\
\hline & Sector La Vega & $5^{\circ} 29^{\prime} 01.7^{\prime \prime} \mathrm{N}$ & $-75^{\circ} 02^{\prime} 18.4^{\prime \prime} \mathrm{W}$ & 1,450 & March-June 2014 \\
\hline & Sector La Vega & $5^{\circ} 28^{\prime} 52.0^{\prime \prime} \mathrm{N}$ & $-75^{\circ} 01^{\prime} 45.7^{\prime \prime} \mathrm{W}$ & 1,375 & 16.08.2017 - 16.09.2017 \\
\hline & Sector La Vega & $5^{\circ} 29^{\prime} 20.0^{\prime \prime} \mathrm{N}$ & $-75^{\circ} 01^{\prime} 39.7^{\prime \prime} \mathrm{W}$ & 1,078 & 27.11.2017 - 17.01.2018 \\
\hline & Predio San Antonio & $5^{\circ} 29^{\prime} 39.1^{\prime \prime} \mathrm{N}$ & $-75^{\circ} 01^{\prime} 27.9^{\prime \prime} \mathrm{W}$ & 1,458 & $06.04 .2016-05.05 .2016$ \\
\hline 10 & Vereda San Vicente, Finca Jose Luis Orozco & $5^{\circ} 31^{\prime} 59.0^{\prime \prime} \mathrm{N}$ & $-75^{\circ} 04^{\prime} 18.1^{\prime \prime} \mathrm{W}$ & 1,700 & 12.12 .2001 \\
\hline \multirow[t]{14}{*}{11} & Vereda San Lucas, cinco minutos abajo casa Miguel Molano, quebrada San Lucas & $5^{\circ} 30^{\prime} 12.4^{\prime \prime} \mathrm{N}$ & $-75^{\circ} 03^{\prime} 13.2^{\prime \prime} \mathrm{W}$ & 1,285 & 10.07.2001 \\
\hline & Microcuenca La Selva, cráter volcán El Escondido, sector Coliadero & $5^{\circ} 30^{\prime} 59.1^{\prime \prime} \mathrm{N}$ & $-75^{\circ} 02^{\prime} 34.5^{\prime \prime} \mathrm{W}$ & 1,478 & 18.10.2017-20.10.2017 \\
\hline & Transecto altitudinal en el sector Coliadero & $5^{\circ} 30^{\prime} 00.0^{\prime \prime} \mathrm{N}$ & $-75^{\circ} 03^{\prime} 00.0^{\prime \prime} \mathrm{W}$ & $1,536-1,809$ & $18.10 .2017-20.10 .2017$ \\
\hline & Microcuenca Chupaderos 1 & $5^{\circ} 29^{\prime} 55.7^{\prime \prime} \mathrm{N}$ & $-75^{\circ} 02^{\prime} 56.5^{\prime \prime} \mathrm{W}$ & 1,309 & 21.04.2018-23.04.2018 \\
\hline & Microcuenca Chupaderos 1 & $5^{\circ} 29^{\prime} 28.6^{\prime \prime} \mathrm{N}$ & $-75^{\circ} 02^{\prime} 45.6^{\prime \prime} \mathrm{W}$ & 1,423 & \\
\hline & Microcuenca Chupaderos 1 & $5^{\circ} 29^{\prime} 40.3^{\prime \prime} \mathrm{N}$ & $-75^{\circ} 02^{\prime} 43.4^{\prime \prime} \mathrm{W}$ & 1,438 & 21.04.2018-23.04.2018 \\
\hline & Río San Antonio & $5^{\circ} 29^{\prime} 54.9^{\prime \prime} \mathrm{N}$ & $-75^{\circ} 02^{\prime} 34.0^{\prime \prime} \mathrm{W}$ & 1,330 & 04.2018 \\
\hline & San Lucas & $5^{\circ} 30^{\prime} 45.0^{\prime \prime} \mathrm{N}$ & $-75^{\circ} 03^{\prime} 07.8^{\prime \prime} \mathrm{W}$ & 1,636 & 21.03.2017 - 14.04.2017; \\
\hline & San Lucas & $5^{\circ} 30^{\prime} 08.2^{\prime \prime} \mathrm{N}$ & $-75^{\circ} 03^{\prime} 41.0^{\prime \prime} \mathrm{W}$ & 1,482 & 28.06.2017 - 30.07.2017 \\
\hline & San Lucas & $5^{\circ} 29^{\prime} 28.6^{\prime \prime} \mathrm{N}$ & $-75^{\circ} 03^{\prime} 14.6^{\prime \prime} \mathrm{W}$ & 1,290 & 29.06.2017 - 30.07.2017 \\
\hline & San Lucas & $5^{\circ} 29^{\prime} 22.6^{\prime \prime} \mathrm{N}$ & $-75^{\circ} 03^{\prime} 04.3^{\prime \prime} \mathrm{W}$ & 1,463 & $29.06 .2017-30.07 .2017$ \\
\hline & San Lucas & $5^{\circ} 28^{\prime} 51.1^{\prime \prime} \mathrm{N}$ & $-75^{\circ} 03^{\prime} 28.9^{\prime \prime} \mathrm{W}$ & 1,581 & 29.08.2017 - 13.10.2017 \\
\hline & San Lucas & $5^{\circ} 30^{\prime} 18.1^{\prime \prime} \mathrm{N}$ & $-75^{\circ} 04^{\prime} 13.1^{\prime \prime} \mathrm{W}$ & 1,719 & $30.08 .2017-14.10 .2017$ \\
\hline & Sector Sierra Morena & $5^{\circ} 30^{\prime} 52.3^{\prime \prime} \mathrm{N}$ & $-75^{\circ} 03^{\prime} 45.5^{\prime \prime} \mathrm{W}$ & 2,034 & $26.04 .2017-15.06 .2017$ \\
\hline \multirow[t]{5}{*}{12} & Vereda La Abundancia, cuenca del Río Hondo & $5^{\circ} 31^{\prime} 01.2^{\prime \prime} \mathrm{N}$ & $-75^{\circ} 05^{\prime} 47.9^{\prime \prime} \mathrm{W}$ & 1,538 & $23.08 .2017-03.10 .2017$ \\
\hline & Cuchilla del Dulce & $5^{\circ} 31^{\prime} 1.34^{\prime \prime} \mathrm{N}$ & $-75^{\circ} 04^{\prime} 53.0^{\prime \prime} \mathrm{W}$ & $1,470-1,800$ & $19.11 .2000-21.11 .2000$ \\
\hline & Mina La Concha, cabecera del riachuelo & $5^{\circ} 30^{\prime} 46.5^{\prime \prime} \mathrm{N}$ & $-75^{\circ} 05^{\prime} 57.4^{\prime \prime} \mathrm{W}$ & 1,980 & 16.04.2001 \\
\hline & Quebrada Seca, 40 minutos aguas arriba vía Florencia-Pueblo Nuevo & $5^{\circ} 31^{\prime} 23.9^{\prime \prime} \mathrm{N}$ & $-75^{\circ} 05^{\prime} 57.7^{\prime \prime} \mathrm{W}$ & 1,800 & 05.07.2001 \\
\hline & Caño Las Agüitas & $5^{\circ} 31^{\prime} 12.1^{\prime \prime} \mathrm{N}$ & $-75^{\circ} 05^{\prime} 22.4^{\prime \prime} \mathrm{W}$ & 1,573 & \\
\hline 13 & Vereda Río Claro, sector Bocatomas & $5^{\circ} 30^{\prime} 22.0^{\prime \prime} \mathrm{N}$ & $-75^{\circ} 02^{\prime} 21^{\prime \prime} \mathrm{W}$ & 1,300 & 07.10 .2017 \\
\hline \multirow[t]{2}{*}{14} & Vereda La Bretaña & $5^{\circ} 31^{\prime} 44.3^{\prime \prime} \mathrm{N}$ & $-75^{\circ} 03^{\prime} 58.1^{\prime \prime} \mathrm{W}$ & 1,819 & $10.06 .2017-13.07 .2017$ \\
\hline & Vereda La Bretaña & $5^{\circ} 31^{\prime} 44.4^{\prime \prime} \mathrm{N}$ & $-75^{\circ} 04^{\prime} 13.4^{\prime \prime} \mathrm{W}$ & 1,783 & $17.05 .2017-21.06 .2017$ \\
\hline
\end{tabular}


Table 1. Continuation...

\begin{tabular}{|c|c|c|c|c|c|}
\hline & Code / Locality & Latitude & Longitude & Elevation (masl) & Date \\
\hline \multirow[t]{2}{*}{15} & Vereda Las Encimadas & $5^{\circ} 29^{\prime} 04.7^{\prime \prime} \mathrm{N}$ & $-75^{\circ} 00^{\prime} 43.5^{\prime \prime} \mathrm{W}$ & 1,008 & 05.07.2017- 09.08.2017 \\
\hline & Vereda Las Encimadas & $5^{\circ} 29^{\prime} 08.6^{\prime \prime} \mathrm{N}$ & $-75^{\circ} 01^{\prime} 06.5^{\prime \prime} \mathrm{W}$ & 1,361 & $25.10 .2017-26.11 .2017$ \\
\hline \multicolumn{6}{|c|}{ Municipality of Samaná, “Corregimiento” Encimadas, } \\
\hline \multirow[t]{3}{*}{16} & Vereda Yarumalito, sector cuchilla El Micay & $5^{\circ} 26^{\prime} 35.8^{\prime \prime} \mathrm{N}$ & $-75^{\circ} 03^{\prime} 43.8^{\prime \prime} \mathrm{W}$ & 1,856 & $23.05 .2016-01.06 .2016$ \\
\hline & Vereda Yarumalito, sector cuchilla El Micay & $5^{\circ} 26^{\prime} 40.6^{\prime \prime} \mathrm{N}$ & $-75^{\circ} 03^{\prime} 44.2^{\prime \prime} \mathrm{W}$ & 1,873 & \\
\hline & Vereda Yarumalito, sector cuchilla El Micay & $5^{\circ} 26^{\prime} 36.5^{\prime \prime} \mathrm{N}$ & $-75^{\circ} 03^{\prime} 50.9^{\prime \prime} \mathrm{W}$ & 2,306 & 19.07.2017 - 22.08.2017 \\
\hline \multirow[t]{4}{*}{17} & Vereda El Quindío & $5^{\circ} 26^{\prime} 42.5^{\prime \prime} \mathrm{N}$ & $-75^{\circ} 02^{\prime} 09.6^{\prime \prime} \mathrm{W}$ & 1,513 & 20.06.2017 - 21.07.2017 \\
\hline & Vereda El Quindío & $5^{\circ} 26^{\prime} 11.6^{\prime \prime} \mathrm{N}$ & $-75^{\circ} 02^{\prime} 48.0^{\prime \prime} \mathrm{W}$ & 1,744 & $20.10 .2017-22.11 .2017$ \\
\hline & Vereda El Quindío & $5^{\circ} 26^{\prime} 46.6^{\prime \prime} \mathrm{N}$ & $-75^{\circ} 02^{\prime} 21.8^{\prime \prime} \mathrm{W}$ & 1,409 & $31.07 .2018-04.09 .2018$ \\
\hline & Sector Los Planes & $5^{\circ} 26^{\prime} 56.0^{\prime \prime} \mathrm{N}$ & $-75^{\circ} 01^{\prime} 42.2^{\prime \prime} \mathrm{W}$ & 1,471 & $21.06 .2016-21.07 .2016$ \\
\hline \multirow[t]{3}{*}{18} & Vereda El Diamante & $5^{\circ} 28^{\prime} 05.5^{\prime \prime} \mathrm{N}$ & $-75^{\circ} 02^{\prime} 06.1^{\prime \prime} \mathrm{W}$ & 1,552 & $22.06 .2017-25.07 .2017$ \\
\hline & Vereda El Diamante & $5^{\circ} 27^{\prime} 19.1^{\prime \prime} \mathrm{N}$ & $-75^{\circ} 01^{\prime} 15.2^{\prime \prime} \mathrm{W}$ & 1,374 & $21.06 .2017-26.07 .2017$ \\
\hline & Predio El Retiro & $5^{\circ} 27^{\prime} 44.0^{\prime \prime} \mathrm{N}$ & $-75^{\circ} 01^{\prime} 36.3^{\prime \prime} \mathrm{W}$ & 1,384 & 23.06.2017 - 25.07.2017 \\
\hline \multirow[t]{4}{*}{19} & Vereda Santa Isabel & $5^{\circ} 27^{\prime} 21.7^{\prime \prime} \mathrm{N}$ & $-75^{\circ} 04^{\prime} 28.1^{\prime \prime} \mathrm{W}$ & 1,917 & 04.07.2017 - 09.08.2017 \\
\hline & Vereda Santa Isabel & $5^{\circ} 26^{\prime} 58.4^{\prime \prime} \mathrm{N}$ & $-75^{\circ} 04^{\prime} 31.8^{\prime \prime} \mathrm{W}$ & 1,861 & 03.07.2017 - 07.08.2017 \\
\hline & Río Tenerife & $5^{\circ} 28^{\prime} 19.6^{\prime \prime} \mathrm{N}$ & $-75^{\circ} 05^{\prime} 18.4^{\prime \prime} \mathrm{W}$ & 1,559 & $25.09 .2017-26.10 .2017$ \\
\hline & Sector La Gruta & $5^{\circ} 27^{\prime} 03.8^{\prime \prime} \mathrm{N}$ & $-75^{\circ} 03^{\prime} 51.1^{\prime \prime} \mathrm{W}$ & 1,870 & 19.06.2018 - 24.07.2018 \\
\hline
\end{tabular}

mouse opossum, Marmosa regina, the latter considered a senior synonym of M. isthmica by Giarla and Voss 2020) which are differentiated based on size (Appendix 1), tail and coat coloration, and skull morphology.

Eulipotyphla. We recorded only one species (Cryptotis colombianus), based on a male specimen (MHN-UCa 193: skin and skull) collected in the San Vicente village, 1,700 m (28 December 2001). External measurements are: TL: 96, HB: 69, Tail: 27, feet: 12, W: 7 g. LT/HB: $39.13 \%$. Cranio-dental skull measurements are: condylobasal length: 19.68 , cranial amplitude: 9.53 , zygomatic plate width: 3.91 , interorbital width: 40.8 , length of unicuspid teeth row: 3.78 , mandibular length: 7.50, mandibular tooth row length: 5.38 , width between upper second molars: $6.00 \mathrm{~mm}$. One additional specimen of Cryptotis was captured but not collected in 2014 and the specific identity is uncertain.

Cingulata and Pilosa. We registered five species in the study area. One species of Cingulata (Dasypus novemcinctus) and two of Pilosa (Choloepus hoffmanni and Tamandua mexicana) were documented using direct observations and indirect records (bones). Cyclopes dorsalis was photographed in 2012 near to a farm in the study area. Based on camera traps, we obtained seven records of Cabassous centralis in June, October, and November 2017, in three locations at of 1,361, 1,744 and 1,783 masl. Similarly, we obtained a total of 17 records for $D$. novemcinctus during June to September and December 2017 and in February and May 2018, in 11 locations located at elevations between 1,078 and 1,999 m. For Pilosa, we obtained eight records of T. mexicana between July and October 2017 in six locations with elevations between 1,008 and $1,719 \mathrm{~m}$.

Chiroptera. We registered a total of 30 species of two families (Phyllostomidae and Vespertilionidae; Table 2). Bats were the best represented group in terms of richness with 12 (152 captured individuals) and 16 species (179 individuals captured), during 2000 to 2001 and 2017 to 2018, respectively. The most abundant species was Carollia brevicauda with 17 (2000 to 2001) and 100 (2017 to 2018) captured individuals. We highlight the presence of three species of small Artibeus (anderseni, bogotensis, and glaucus) (Appendix 1), which are differentiated based on the number of lower molars (two or three), and skull morphology.

Carnivora. We registered a total of 13 species of Canidae, Felidae, Mustelidae, and Procyonidae (Table 1). During 2000 and 2001, we recorded nine species based on indirect records. During 2017 to 2018 we registered four species based on indirect records and observations, one of them (Bassaricyon neblina) had no previous records at the NNP or for the Department of Caldas. The specimen was identified as N. neblina based on the long dorsal hair coat, dense and of rufous coloration with black tips, the fur of the belly pale yellowish; the face has a medium and pointed muzzle of dark-gray coloration, eyes are big and brown, ears are rounded with hairs, and the tail is proportionately short (412 mm), bushier and straight becoming darker at the tip. In camera traps, we obtained total of 19 records of individuals of the four families. Among these, four records of Eira barbara (Mustelidae) in July, October, and December 2017 and May 2018, in four locations located at elevations between 1,692 and 1,599 m. For Procyonidae, we obtained five records of Nasua nasua between June and September 2017, and May 2018 in five localities between 1,463 and $1,999 \mathrm{~m}$. In addition, a record of Procyon cancrivorus in July 2017 at 1,917 m elevation. For Felidae, we recorded Herpailurus yagouaroundi in September 2017 in a locality at 1,375 m; six records of Leopardus pardalis between June and September 2017, and February 2018, in five localities at elevations between 1,382 and 2,306 m. In addition, four 


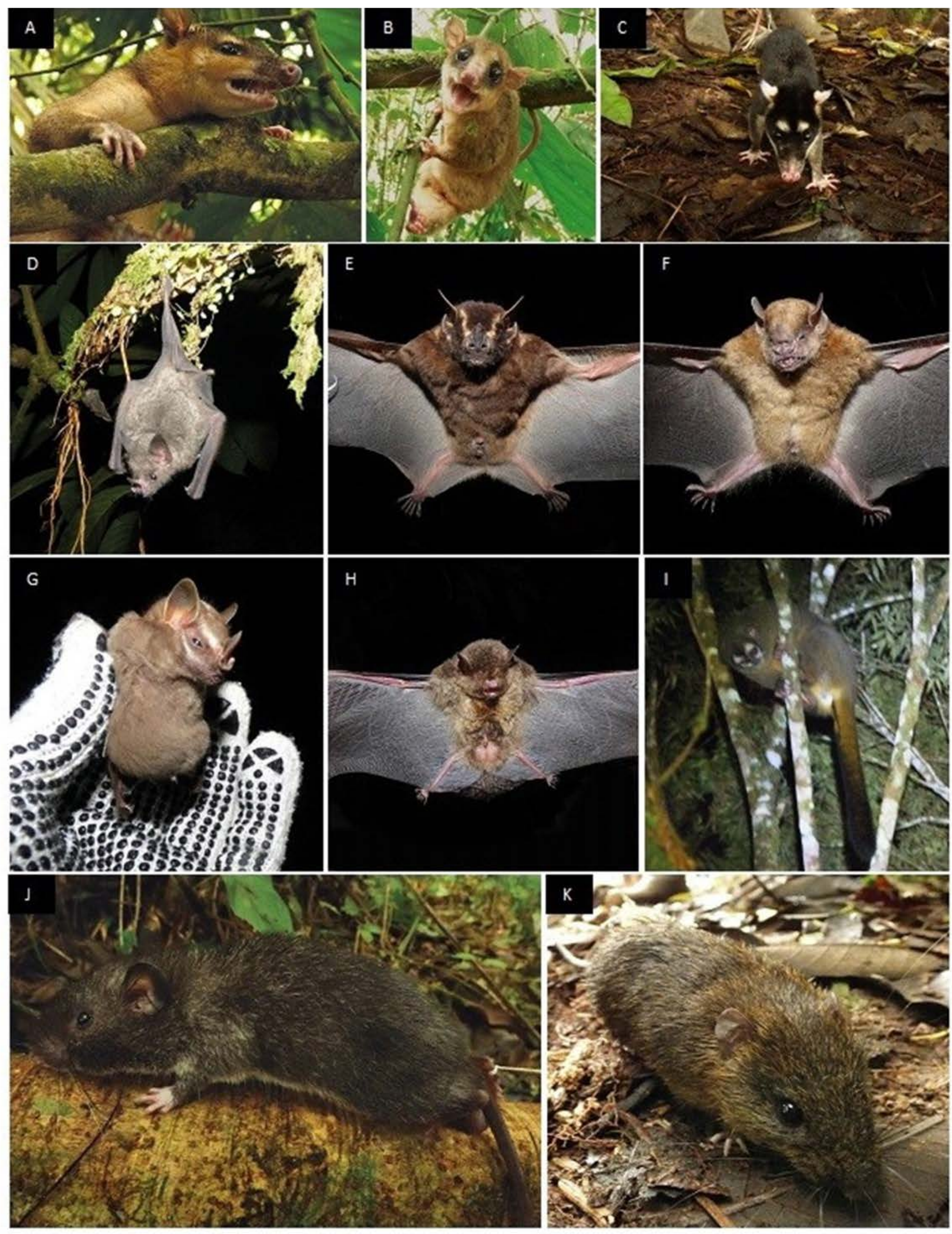

Figure 2. Small mammal species captured and observed in 2017 and 2018: Didelphimorphia: A) Metachirus myosuros. B) Marmosa regina/isthmica. C) Philander melanurus. Chi-

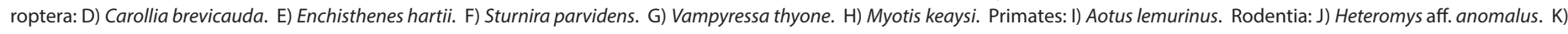
Neacomys tenuipes. 
records of L. wiedii in August and September 2017, and April 2018, in three localities with elevations between 1,719 and 2,306 m. Finally, in May and June 2017, we reported L. tigrinus twice in different locations at 1,374 and 1,738 m elevation. Cranial measurements of three specimens from the study area are shown in Appendix 1.

Artiodactyla. We confirmed the presence of two families (Cervidae and Tayassuidae) and two species. Dicotyles tajacu (Tayassuidae) was registered based on indirect records and by camera traps (16 events) in July, September, October, and November 2017, and in February, March, and May 2018 at elevations between 1,382 and 1,999 m. The dwarf brocket deer, Mazama rufina (Cervidae) was recorded based on incidental records and observations.

Primates. We reported five species (Aotus lemurinus, Alouatta seniculus, Ateles hybridus, Cebus versicolor and Saguinus leucopus) of three families (Atelidae, Cebidae, and Callitrichidae) by direct observation. A predation event by an unidentified eagle on an individual of Aotus lemurinus was registered by the local community in March 2020.

Rodentia. We registered 16 species from seven families at the NNP Selva de Florencia (Table 1; Appendix 1). During 2000 and 2001, we reported seven species, five captured individuals and three species, based on dead specimens or bone fragments. During 2017 to 2018, rodents contributed with five species (19 captured individuals and two species recorded by dead specimens or bone fragments), with Heteromys aff. anomalus as the most abundant with 13 captures. We reported two species of Nephelomys which are differentiated based on the frequency of ventral white patches, the size of the posterolateral palatal pits and the shape of the palatal fossae. Using camera traps, we found that Dasyprocta punctata and Cuniculus paca were the species with the highest number of records (125 and 56, respectively). In addition, we obtained 14 records of Syntheosciurus granatensis plus 133 of unidentified rodents.

The BLAST query with our sequence of Coendou quichua recovered two sequences from GenBank (accessions and KC863881) with percentages of identity of $98.86 \%$ and $95.87 \%$. The first (KC463882) was obtained from another Colombian specimen (Department of Cesar), whereas the second corresponds to an Ecuadorian specimen. This result unequivocally supports that the specimen we collected in the NNP Selva de Florencia belongs to this species.

Our sequences of $\mathrm{H}$. aff. anomalus obtained identity values of $90.18 \%$ and $90.04 \%$ with sequences of $H$. australis (GU646927 and GU646928) from Panama, and $90.18 \%$ with sequences of $H$. anomalus from Venezuela (DQ168468). This result suggests that specimens from the Selva de Florencia Natural Park identified morphologically as $H$. aff. anomalus, cannot be assigned to this species on basis on molecular data. The percentages of identity below $95 \%$ with respect to all Cytb sequences of the genus even indicate they are not assignable to any of the known species (at least those genetically characterized for this marker). The name Heteromys (Heteromys) anomalus hershkovitzi Hernández-Camacho, 1956 was suggested for populations of this genus from the Magdalena River basin in Colombia, and it is an available name for this taxon. The assignation and revalidation of this name to the populations of Selva de Florencia identified as $\mathrm{H}$. aff. anomalus is needed.

For Neacomys tenuipes, our two sequences are $100 \%$ identical. The highest genetic score (93.02\%) was obtained with a sequence of $N$. rosalindae (KY859763) from Peru. The only sequence of $N$. tenuipes available in GenBank (also from Colombia) was not recovered in the queries, probably due to its short length (only $177 \mathrm{bp}$ ). Thus, with identities below $95 \%$ with respect to other Neacomys Cytb sequences in Genbank, and without larger sequences of $N$. tenuipes available to compare, specimens of the NNP Selva de Florencia cannot be molecularly assigned to any species in the genus. However, considering these specimens present all the morphological diagnostic character for $\mathrm{N}$. tenuipes, sequences generated here can be considered the most complete publicly available. Finally, for our sequence of $S$. alfari, four matches with highest percentages of identity were of the same species: $96.88 \%$ compared to an Ecuadorian specimen (EU340016), and three with the same value of $95.61 \%$ from specimens collected in Panama (KY754155, GU126548, EU074635).

Threatened categories and endemic species. We identified eight species listed in threatened categories according to the national legislation (MADS 2017), and in the Red List of the International Union for the Conservation of Nature and Natural Resources (IUCN 2019). The most threatened species include the primates Ateles hybridus (Critically Endangered - CR), Aotus lemurinus (Vulnerable - VU), Cebus versicolor and Saguinus leucopus (Endangered - EN), the latter is considered Vulnerable according to Colombian legislation (MADS 2017). Other species in a threaten category include the carnivores Leopardus tigrinus and Lontra longicaudis, the dwarf brocket deer Mazama rufina (all listed globally as VU), and the pacarana Dinomys branickii listed as VU in Colombia (MADS 2017). The endemic species registered are: Cryptotis colombianus distributed in one ecoregion (the Magdalena Valley Montane Forest), Saguinus leucopus distributed in two ecoregions (Magdalena-Urabá Moist Forests, and Nephelomys pectoralis in two (Cauca Valley Montane Forests, and Northwest Andean Montane Forests), Nephelomys childi in three (Cauca Valley Montane Forests, Cordillera Oriental Montane Forests, and Northwest Andean Montane Forests), Marmosops chucha, distributed in four ecoregions (Cauca Valley Dry Forests, Magdalena-Urabá Moist Forests, Northwest Andean Montane Forests, and Magdalena Valley Montane Forests), and Cebus versicolor in five ecoregions (Guajira-Barranquilla Xeric Scrub, Magdalena-Urabá Moist Forests, Magdalena Valley Dry Forests, Magdalena Valley Montane Forests, and Sinú Valley dry Forests). 


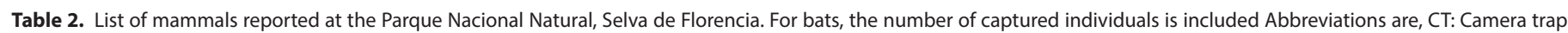

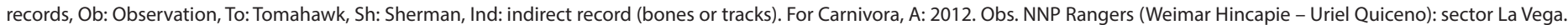

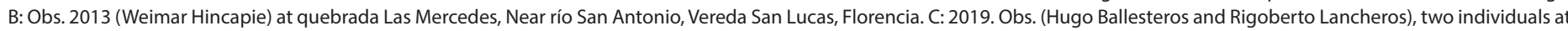

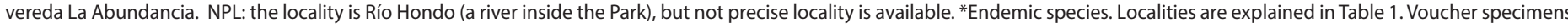
are housed at the MNH-UCa unless otherwise specified.

\begin{tabular}{|c|c|c|c|c|}
\hline \multirow{2}{*}{ Taxon } & \multicolumn{2}{|c|}{ Year } & \multirow{2}{*}{ Vouchers or type of record } & \multirow{2}{*}{ Localities } \\
\hline & $2000-2001$ & 2017-2018 & & \\
\hline \multicolumn{5}{|l|}{ DIDELPHIMORPHIA } \\
\hline Chironectes minimus & $1 \mathrm{Ob}$ & & 218 & 12 \\
\hline Didelphis marsupialis & $1 \mathrm{To}, 2 \mathrm{Ob}$ & & $208,2427-2428$ & 11 \\
\hline Marmosa regina/isthmica & & $1 \mathrm{Sh}$ & 1612, FMNH 70978 & $8, N P L$ \\
\hline Marmosa sp. & & & 876 & 2 \\
\hline Marmosops chucha* & & & FMNH 70925 & NPL \\
\hline Metachirus myosuros & & $1 \mathrm{Sh}$ & 1613,3165 & 8 \\
\hline Monodelphis adusta & & & 227 (lost); 263 & NPL \\
\hline Philander melanurus & & $1 \mathrm{Sh}$ & 1614 & 8 \\
\hline \multicolumn{5}{|l|}{ EULIPOTYPHLA } \\
\hline Cryptotis colombianus & 1 & & 193 & 10 \\
\hline \multicolumn{5}{|l|}{ CINGULATA } \\
\hline Cabassous centralis & & & $4 \mathrm{CT}$ & $14,15,17$ \\
\hline Dasypus novemcinctus & & & $201,1800,2430,(18 C T)$ & $6,8,9,11,14,17,18,19$ \\
\hline \multicolumn{5}{|l|}{ PILOSA } \\
\hline Cyclopes dorsalis & & & Photographs & NPL \\
\hline Choloepus hoffmanni & & 1 obs & $197,1615,2424-2425,3160-3163$ & 11,13 \\
\hline Tamandua mexicana & & & 2426, (8 CT) & $1,9,11,14,15,18$ \\
\hline \multicolumn{5}{|l|}{ CHIROPTERA } \\
\hline \multicolumn{5}{|l|}{ Phyllostomidae } \\
\hline Carollia brevicauda & 1 & 100 & $\begin{array}{c}019-032,035,037,043,048,055,062,065,069-074,076,083,088,095,097,099- \\
100,166-168,175,236,239,243,1603,1634,1635,1638\end{array}$ & $3,8,11,12$ \\
\hline Carollia castanea & & 18 & $1636 ; 1637 ; 1673$ & $3, N P L$ \\
\hline Carollia perspicillata & & 9 & $22,91,1672$ & $3, N P L$ \\
\hline Desmodus rotundus & 1 & & Interviews & \\
\hline Anoura cultrata & 2 & & 94,171 & 2,10 \\
\hline Anoura fistulata & 1 & & 44 & 3 \\
\hline Anoura caudifer & 4 & & $58,59,60,78$ & 12 \\
\hline Anoura geoffroyi & 1 & & & NPL \\
\hline Micronycteris megalotis & & 1 & 1632 & 8 \\
\hline Artibeus lituratus & & 6 & $1639,1640,1678$ & $11, \mathrm{NPL}$ \\
\hline Artibeus anderseni & & 5 & 1641 & 11 \\
\hline Artibeus bogotensis & & 3 & 1642 & 11 \\
\hline Artibeus glaucus & 1 & & 0172 & 10 \\
\hline Chiroderma salvini & 2 & & 0067,0081 & 12 \\
\hline Enchisthenes hartii & 1 & 1 & $66,77,237,240,259,1633$ & 11,12 \\
\hline Phyllostomus discolor & 1 & & 0089 & 11 \\
\hline Platyrrhinus albericoi & & 3 & 1644,1645 & 11 \\
\hline Platyrrhinus dorsalis & 1 & & $0034,0082,0087,0090$ & 11,12 \\
\hline Platyrrhinus helleri & 1 & 7 & $0045,1643,1663$ & 11 \\
\hline Platyrrhinus ismaeli & 1 & & $0038,0063,0085,0170$ & $10,11,12$ \\
\hline Sturnira bogotensis & & 5 & $0042,0047,0084,0093,1056,1652,1654$ & $11,12, N P L$ \\
\hline Sturnira erythromos & & & $0080,0084,0234$ & 12 \\
\hline Sturnira parvidens & 1 & 6 & $24-25,29,39-41,49,51,53-54,64,68,1649,1651,1678$ & $8,11,12$ \\
\hline Sturnira oporaphilum & 1 & 8 & 0061 & 12 \\
\hline Vampyressa thyone & & 5 & $0073,1646,1647,1676$ & $8,11,12$ \\
\hline
\end{tabular}


Table 2. Continuation...

\begin{tabular}{|c|c|c|c|c|}
\hline \multirow{2}{*}{ Taxon } & \multicolumn{2}{|c|}{ Year } & \multirow{2}{*}{ Vouchers or type of record } & \multirow{2}{*}{ Localities } \\
\hline & $2000-2001$ & 2017-2018 & & \\
\hline \multicolumn{5}{|l|}{ VESPERTILIONIDAE } \\
\hline Eptesicus chiriquinus & 1 & & 147 & 12 \\
\hline Myotis caucensis & 1 & & 50,152 & 12 \\
\hline Myotis riparius & & 2 & 1657,1658 & 11 \\
\hline Myotis keaysi & & 1 & 1659 & 11 \\
\hline \multicolumn{5}{|l|}{ CARNIVORA } \\
\hline Leopardus pardalis & & 1 & (8CT), Ind. & $6,9,14,17,18$ \\
\hline Leopardus tigrinus & & & $205,(2 C T)$ & $9,14,18$ \\
\hline Leopardus wiedii & & & $4 \mathrm{CT}$, photographs & $6,11,14$ \\
\hline Herpailurus yagouaroundi & & & $1 \mathrm{CT}$, photographs & 9 \\
\hline Puma concolor & & & Skull, FMNH 70567 & NPL \\
\hline Cerdocyon thous & 1 & & Skull, 0200 & NPL \\
\hline Eira barbara & & & (6 CT) & $5,6,7,1418$ \\
\hline Bassaricyon neblina & & 1 & 1631 & 13 \\
\hline Nasua nasua & 1994 & 1 & $(6 \mathrm{CT}), \mathrm{IAvH} 7318$ & $6,11,14,17,19, \mathrm{NPL}$ \\
\hline Potos flavus & 1 & 1 & 3164, Obs, video & 10 \\
\hline Procyon cancrivorus & & & (1 CT), photographs & 19 \\
\hline Lontra longicaudis & & & $A, B, C$. & 12 \\
\hline Mustela frenata & & 1 & Obs. & 2 \\
\hline \multicolumn{5}{|l|}{ ARTIODACTYLA } \\
\hline Mazama rufina & & 1 & Obs. & 3 \\
\hline Pecari tajacu & & & $1668,(17 \mathrm{CT})$ & $5,6,7,9,11,14,18$ \\
\hline \multicolumn{5}{|l|}{ PRIMATES } \\
\hline Alouatta seniculus & & 1- 9 ind & 3159, Obs. & $\begin{array}{c}4,6,7,8,9,11,12,15,17 \\
18,19, \mathrm{NPL}\end{array}$ \\
\hline Ateles hybridus & & 3 ind & Obs. & $4,9,16$ \\
\hline Aotus lemurinus & & 3 ind & Obs. & 11,16 \\
\hline Cebus versicolor* & & $1-15$ ind & Obs. & $6,11,12,17,18$ \\
\hline Saguinus leucopus* & & $1-14$ ind & Obs. & $2,8,9,15,16,17,19$ \\
\hline \multicolumn{5}{|l|}{ RODENTIA } \\
\hline Syntheosciurus granatensis & 1 & Obs & $16 \mathrm{CT}$ & $5,7,9,11,14,17,18,19$ \\
\hline Leptosciurus pucheranii & & 1 & Photographs & $1,2,5,16,18$ \\
\hline Heteromys australis & 1 & & FMNH 71185-71190 & NPL \\
\hline Heteromys aff. anomalus & & $13 \mathrm{Sh}$ & $1617,1618,1619,1620$ & 11 \\
\hline Handleyomys alfaroi & & & FMNH 72062, 72073-72075, 72077-72080 & NPL \\
\hline Melanomys caliginosus & & & FMNH 71816-71822 & NPL \\
\hline Neacomys tenuipes & & $5 \mathrm{Sh}, 1 \mathrm{ma}$ & $1627,1628,1692$ & $8, N P L$ \\
\hline Nephelomys childi* & 1 & & 771,772 & 12 \\
\hline Nephelomys pectoralis* & & & $185,188,189,190$ & 12 \\
\hline Sigmodontomys alfari & & $1 \mathrm{Sh}$ & 1630 & 8 \\
\hline Tylomys mirae & & & FMNH 71215 & NPL \\
\hline Transandinomys talamancae & & & FMNH 72063, 72066 & NPL \\
\hline Rhipidomys latimanus & 1 & & $1690-1691$ & 7 \\
\hline Coendou quichua & & 2 ind & $1616,2422-2423,(1 \mathrm{CT})$ & 11 \\
\hline Cuniculus paca & 1 & & $1811-1812,(58 \mathrm{CT})$ & $5,9,11,14,17,18,19, \mathrm{NPL}$ \\
\hline Dasyprocta punctata & 1 & 1 ind & $1607,(136 \mathrm{CT})$ & $7,9,11,14,15,17,18,19$ \\
\hline Dinomys branickii & & & 216-217, 883, (1 CT), 1 Photograph, IAvH 19984 & $10,17, \mathrm{NPL}$ \\
\hline
\end{tabular}




\section{Discussion}

To our knowledge, the inventory of mammalian species at the NNP Selva de Florencia is one of the most complete for a protected area in the Colombian Andes. This information complements previous inventories for this sector of the country (Castaño et al. 2003; Castaño Salazar 2012; Acosta Castañeda et al. 2014) and becomes a base tool for the formulation of new mammal research and conservation strategies on a regional scale. Furthermore, the genetic characterization performed here for some of the species constitutes a valuable approach to explore mammal richness in Colombia, and particularly within protected areas.
Despite the mammal richness documented for the NNP Selva de Florencia is high $(16.30 \%$ of the terrestrial mammals from Colombia; Ramírez-Chaves et al. 2020a), many of the small mammal species registered probably require further assessments of their variation, and therefore, of its taxonomic status and distributional limits. For example, both species of genus Nephelomys recorded in this study are likely out of the distributional ranges suggested in a recent study based on morphometric and limited genetic data (Cárdenas 2017). Cárdenas (2017) mentioned that for Colombia, N. childi is restricted to the Eastern Cordillera, N. pectoralis is distributed in the Western Cordillera, and specimens from the Central Cordillera belong to an undescribed
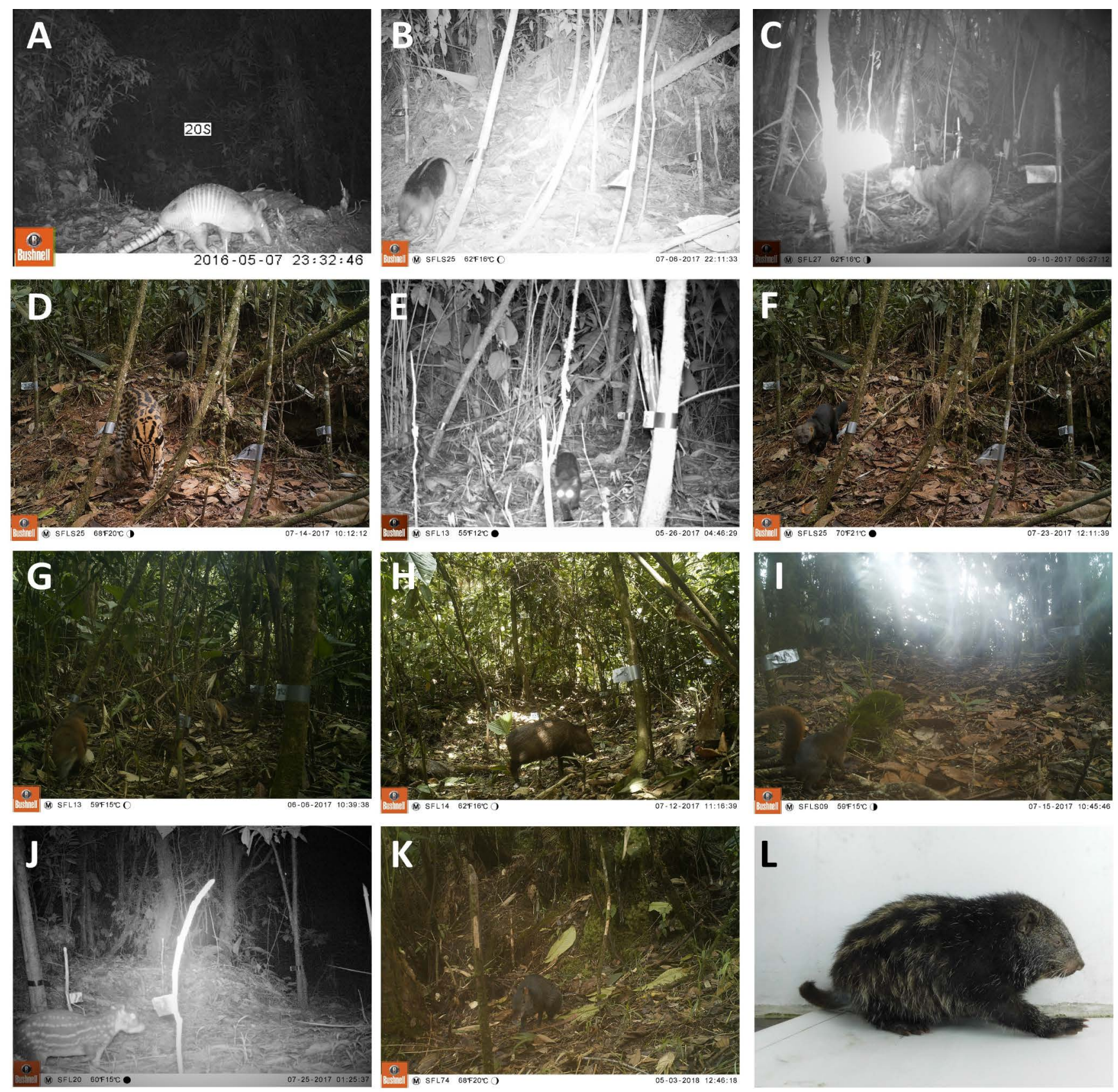

Figure 3. Medium and large mammals registered using camera traps and direct observations in Selva de Florencia. Cingulata: A) Dasypus novemcinctus. Pilosa: B) Tamandua me-

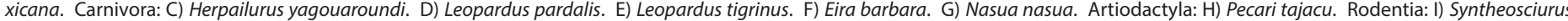
granatensis. J) Cuniculus paca. K) Dasyprocta punctata. L) Dinomys branickii. 
taxon (Nephelomys sp1.). In contrast, Percequillo (2015) considered that $N$. childi is present in the three Colombian Cordilleras. Therefore, the inclusion of more specimens from both mountain ranges and the north of the Department of Caldas is required to clarify the species inhabiting in this area of Colombia. This implies conducting additional field expeditions, collecting new individuals, and performing a complete molecular characterization. Molecular data (Cytb) of some of the species characterized here reflect higher divergence values (ca. $4 \%$ ) than those that have traditionally been used to separate sister species in mammals (Bradley and Baker 2001). This might reflect that a large portion of this diversity surely represents hidden or cryptic diversity (see Bickford et al. 2007), and in most cases only molecular information (even from a single marker, as Cytochrome b or Cytochrome C Oxidase Subunit 1) might offer enough resolution to detect it (Bradley and Baker 2001).

In some groups especially, such as rodents, shrews, marsupials, and bats, taxonomy has changed dramatically in recent years with the introduction of molecular data in revisionary works, allowing multiple species to be discriminated from what was once considered a single species ( $e$. g., Basantes et al. 2020; Voss et al. 2020). Despite that, there are few examples including material from Colombia (DíazNieto et al. 2016; Franco-Sierra and Díaz-Nieto 2020; Voss et al. 2020), which reflects a delay in the implementation of modern methods for studying mammals in the country. Even though in this work we obtained Cytb sequences of common and widely distributed rodent species (Patton et al. 2015), most of them have been poorly characterized at the genetical level. For instance, our sequence of $C$. quichua is the fourth for the species (second from Colombia) showing intraspecific divergences reaching the range observed between species (Voss et al. 2013). Similarly, the sequences of $N$. tenuipes are between the first for the species (Colmenares-Pinzón 2021), and that of Sigmodontomys alfari is the fifth for the species (first for Colombia). For Heteromys aff. anomalus the sequences are the first molecular data from Colombian populations that will be publicly available, and the genetic distances are larger than most of the interspecific values (Rogers and González 2010). In contrast, for Sigmodontomys the distances are within the intraspecific ranges observed for other cricetids (e. g., Melanomys; Hanson and Bradley 2008). In addition, the taxonomy of the rodent species characterized here for the Cytb (all rodents) has relied principally on morphology and has remained stable, and none of them have included material collected in protected areas (see Patton et al. 2015). These efforts must also be replicated for other species of small mammals such as marsupials and shrews, for which cryptic diversity has been observed in Colombia (Díaz-Nieto et al. 2016; Noguera-Urbano et al. 2019).

The endemic species registered at the NNP Selva de Florencia are typical elements of the Andean region and its interAndean valleys and ecoregions (Nor-Andean and ChocóMagdalena Biogeographic Provinces; Hérnandez Camacho et al. 1992). Other species documented are more widely distributed in the country and are withing the elevational ranges known for the country (see Solari et al. 2013; Patton et al. 2015). Although the species of mammals recorded in this work were expected at the NNP Selva de Florencia, we highlight the records of the olinguito (Bassaricyon neblina), and the Caribbean spiny pocket mouse (Heteromys aff. anomalus), that were not previously registered for the Department of Caldas (Castaño Salazar 2012). Of these, the olinguito has been included as the species of Procyonidae with the highest priority and need for research in Colombia (Andrade-Ponce et al. 2016). In addition, the presence of species in different threaten categories is highlighted, among which, primates have covered the greatest research efforts (Castaño et al. 2003; Roncancio Duque 2012). Other charismatic and endangered species include felines such as the jaguar (Panthera onca) for which its presence has been suggested in the park (Escobar-Lasso et al. 2014). Finally, for the endemic species, additional analyses integrating biogeographic aspects, molecular information and monitoring plans inside the protected areas are needed due to the limited information available for these taxa (Noguera-Urbano et al. 2019; Ramírez-Chaves et al. 2020c).

\section{Acknowledgments}

The sampling carried out between the end of 2017 and the first half of 2018 was carried out within the framework of the project “Caldas, Expedición Siglo XXI. Fase I: Levantamiento de la biota y geología de una subcuenca del Parque Nacional Natural Selva de Florencia", financed by the Vicerrectoría de Investigaciones y Posgrados, Universidad de Caldas, code 1421717 and the Parque Nacional Natural Selva de Florencia. We also thank Vicerrectoría de Investigaciones y Posgrados de la Universidad de Caldas, Project: “Código de barras de los mamíferos del departamento de Caldas: Una herramienta para comprender la biodiversidad del departamento" Code 0743919 and Budget code 201010027758. Thanks to Bruce D. Patterson and The Science and Scholarship Committee of the Field Museum of Natural History, Chicago, for allowing and supporting the review of specimens under their care. We thank all the staff of the Parque Nacional Natural Selva de Florencia, for the logistic support and field work in the study area. Julián Lozano for allowing the review of specimens at the Instituto Alexander von Humboldt (IAvH). The local community of the municipalities of Pensilvania and Samaná, for their hospitality and support. HERC thanks Rufford Small Grants (Grant 294912) for support. Sergio Solari and two anonymous reviewers provided useful comments that improved the manuscript.

\section{Literature cited}

Acosta Castañeda, A., L. M. Calderón Espitia, A. Ramos Duque, A. Herrera Caicedo, J. Echeverry Garzón, D. Villanueva, W. Hincapie, E. Patiño, J. M. Orrego, R. Lancheros, F. Cardona, D. C. Álvarez, O. Marulanda, O. Mahecha, J. J. López, U. Rodrigo Quiceno, D. Sánchez, J. Giraldo, A. Marín, and C. González. 2014. Muestreo Rápido de Biodiversidad en la vereda Las Colonias, 
corregimiento de Pueblo Nuevo, municipio de Pensilvania, ubicado en el PNN Selva de Florencia. Convenio de Cooperación Interinstitucional No. 47- 0044 de 2013. Orden de servicio No. ISAGEN VII-002 de 2014.

Alberico, M., A. Cadena, J. Hernández-Camacho, and Y. MuñozSaba. 2000. Mamíferos (Synapsida: Theria) de Colombia. Biota Colombiana 1:43-75.

Altschul, S. F., W. Gish, W. Miller, E. W. Myers, and D. J. Lipman. 1990. Basic local alignment search tool. Journal of Molecular Biology 215:403-410.

Andrade-Ponce, G., S. M. Montaño-Salazar, L. M. Riveros-Loalza, H. E. Ramírez-Chaves, and A. F. Suárez-Castro. 2016. Estado de conocimiento y prioridades de investigación de las familias Canidae, Mephitidae y Procyonidae (Mammalia: Carnivora) en Colombia. Revista de la Academia Colombiana de Ciencias Exactas, Físicas y Naturales 40:500-513.

Basantes, M., N. Tinoco, P. M. Velazco, M. J. Hofmann, M. E. Rodríguez-Posada, And M. A. Самacho. 2020. Systematics and taxonomy of Tonatia saurophila Koopman and Williams, 1951 (Chiroptera, Phyllostomidae). ZooKeys 915:59-86.

Bickford, D., D. J. Lohman, N. S. Sodhi, P. K.L. Ng, R. Meier, K. Winker, K. K. Ingram, and I. Das. 2007. Cryptic species as a window on diversity and conservation. Trends in Ecology and Evolution 22:148-155.

Bradley, R. D., ANd R. J. Baker. 2001. A test of the genetic species concept: Cytochrome- $b$ sequences and mammals. Journal of Mammalogy 82:960-973.

Cáceres-Martínez, C. H., L. R. Sánchez Montano, A. A. Acevedo, AND J. F. GonzÁlez-MaYA. 2020. Diet of Andean bears in Tamá National Natural Park, Colombia. Ursus 2020(31e10):1-11.

Cárdenas González, C. 2017. Taxonomía y distribución del género de roedores andinos: Nephelomys (Cricetidae: Sigmodontinae) en Colombia. Master dissertation, Universidad Nacional de Colombia-Sede Bogotá, Colombia.

Castaño Salazar, J. H. 2012. Mamíferos de Caldas: un análisis de vacíos de información. Boletín Científico. Centro de Museos. Museo de Historia Natural 16:101-119.

Castaño, J. H., Y. Muñoz-Saba, J. E. Botero, and J. H. Vélez. 2003. Mamíferos del departamento de Caldas - Colombia. Biota Colombiana 4:247-259.

Colmenares-Pinzón, J. 2021. Calling for a reassessment of rodent diversity in Colombia: description of a new species of Neacomys (Cricetidae: Oryzomyini) from the Magdalena Valley, with a new phylogenetic hypothesis for the genus and comments on its diversification. Zootaxa 4920:451-494.

Díaz, M. M., S. Solari, L. F. Aguirre, L. Aguiar, and R. M. Bárquez. 2016. Clave de identificación de los murciélagos de Sudamérica. Publicación Especial Nro. 2 PCMA (Programa de Conservación de los Murciélagos de Argentina). Editorial Magna Publicaciones. Argentina.

Díaz-Nieto, J. F., S. A. Jansa, and R. S. Voss. 2016. DNA sequencing reveals unexpected recent diversity and an ancient dichotomy in the American marsupial genus Marmosops (Didelphidae: Thylamyini). Zoological Journal of the Linnean Society 176(4):914-940.

Escobar-Lasso, S., J. Cerón-Cardona, J.H. Castaño-Salazar, L. Mendieta-Giraldo and O. Ospina-Herrera. 2014. Los felinos silvestres del departamento de Caldas, en la región andina de Colombia: composición, distribución y conservación. Therya 5:575-588.
Franco-Sierra, N. D., And J. F. Díaz-Nieto. 2020. Rapid mitochondrial genome sequencing based on Oxford Nanopore Sequencing and a proxy for vertebrate species identification. Ecology and Evolution 10:3544-3560.

Gardner, A.L. (ED.). 2008. Mammals of South America Volume 1. Marsupials, Xenarthrans, Shrews, and Bats. The University of Chicago Press, Chicago, U.SA.

Giarla, T. C., AND R. S. Voss. 2020. On the Identity of Victoria's Mouse Opossum, Marmosa regina Tomas, 1898. American Museum Novitates 3960:1-16.

Gómez, D., K. Orozco, F. Cardona, M. Pineda, M. L. Bedoya, and D. Ocampo. 2020. Avifauna del Parque Nacional Natural Selva de Florencia (Samaná, Caldas, Colombia): nuevos registros y ampliaciones de distribución. Biota Colombiana 21:40-71.

Hanson, J. D., AND R. D. Bradley. 2008. Molecular diversity within Melanomys caliginosus (Rodentia: Oryzomyini): Evidence for multiple species. Occasional Papers, Museum of Texas Tech University 275:1-11.

Hernández-Camacho, J. 1956. Una subespecie nueva de Heteromys anomalus (Mammalia: Rodentia). Lozania 10:1-15.

Hernández Camacho, J. I., A. H. Guerra, R.O. Quijano, and T. Walschburger. 1992. Unidades biogeográficas de Colombia. Pp. 105-151 in La Diversidad Biológica de Iberoamérica (Halffter, G, ed.). Acta Zoológica Mexicana (n.s.). México.

Hernández-Guzmán, A., E. Payán, and O. Monroy-Vilchis. 2011. Hábitos alimentarios del Puma concolor (Carnivora: Felidae) en el Parque Nacional Natural Puracé, Colombia. Revista de Biología Tropical 59:1285-1294.

International Union For Conservation of Nature. 2019. The IUCN Red List of Threatened Species. UICN. https://www.iucnredlist.org/. Consulted the 03-11-2019.

MADS - Ministerio del Ambiente y Desarrollo Sostenible. 2017. Resolución No. 1912. "Por la cual se establece el listado de las especies silvestres amenazadas de la diversidad biológica colombiana continental y marino costera que se encuentran en el territorio nacional, y se dictan otras disposiciones". Bogotá, 15 September 2017.

Mantilla-Meluk, H., F. Mosquera-Guerra, F. Trujillo, N. Pérez, A. Velásquez-Valencia, and A. Vargas Pérez. 2018. Mamíferos del sector norte del Parque Nacional Natural Serranía de Chiribiquete. Revista Colombia Amazónica 10:21-56.

Noguera-Urbano, E. A., J. E. Colmenares-Pinzón, J. Villota, A. Rodríguez-Bolaños, and H. E. Ramírez-Chaves. 2019. Shrews (Cryptotis) of Colombia: What do we know about them? Therya 10:131-147.

Olson, D. M., E. Dinerstein, E. D. Wikramanayake, N. D. Burgess, G. V. N. Powell, E. C. Underwood, J. A. D'Amico, H. E. Strand, J. C. Morrison, C. J. Loucks, T. F. Allnutt, J. F. Lamoreux, T. H. Ricketts, I. Itoua, W. W. Wettengel, Y. Kura, P. Hedao, And K. Kassem. 2001. Terrestrial ecoregions of the world: a new map of life on Earth: a new global map of terrestrial ecoregions provides an innovative tool for conserving biodiversity. BioScience 51:933-938. Paiba-Alzate, J. E., N. López-Orozco, and A. F. Betancourt. 2010. Nuevos registros de aves para el Parque Nacional Natural Selva de Florencia, Caldas. Boletín Científico, Centro de Museos, Museo de Historia Natural 14:114-120.

Patton, J. L., U. F. J. Pardiñas, And G. D’Elía. (eds.). 2015. Mammals of South America Volume 2. Rodents. The University of Chicago Press, Chicago, U.S.A. 
Percequillo, A.R. 2015. Genus Nephelomys. Pp. 377-390 in Mammals of South America Volume 2 Rodents (Patton, J. L., U. F. J. Pardiñas, and G. D'Elía, eds.). The University of Chicago Press. Chicago, U.S.A.

Polanco-Ochoa, R., V. Jaimes, and W. Piragua. 2000. Los mamíferos del Parque Nacional Natural La Paya, Amazonía colombiana. Revista de la Academia Colombiana de Ciencias Exactas, Físicas y Naturales 23:671-682.

Ramírez-Chaves, H. E., A. F. Suárez-Castro, and J. F. GonzálezMaYA. 2016. Cambios recientes a la lista de mamíferos de Colombia. Mammalogy Notes 3:1-9.

Ramírez-Chaves, H. E., A. F. Suárez Castro, Sociedad Colombiana de Mastozoología, D. Zurc, D. C. Concha Osbahr, A. Trujillo, E. A. Noguera Urbano, G. E. Pantoja Peña, M. E. Rodríguez Posada, J. F. González Maya, J. Pérez Torres, H. Mantilla Meluk, C. López Castañeda, A. Velásquez Valencia, and D. Zárrate Charry. 2020a. Mamíferos de Colombia. Versión 1.4. Sociedad Colombiana de Mastozoología. Checklist dataset https://doi. org/10.15472/kl1whs. Accessed on 26 November 2019.

Ramírez-Chaves, H. E., D. Velásquez-Guarín, I. Y. Mejía-Fontecha, J. D. Ocampo, and N. D. Castaño Ramírez. 2020b. Colección de Mamíferos (Mammalia) del Museo de Historia Natural de la Universidad de Caldas, Colombia. Biota Colombiana 21:156-166.

Ramírez-Chaves, H. E., E. A. Noguera-Urbano, D. Morales-Martínez, D. Zurc, A. F. Vargas-Arboleda, and H. Mantilla-Meluk. 2020c. Endemic bats (Mammalia: Chiroptera) of Colombia: State of knowledge, distribution, and conservation. Universitas Scientiarium 25:55-94.

Rogers, D. S., ANd M. W. González. 2010. Phylogenetic relationships among spiny pocket mice (Heteromys) inferred from mitochondrial and nuclear sequence data. Journal of Mammalogy 91:914-930.

Roncancio Duque, N. 2012. A record of the variegated spider monkey (Ateles hybridus brunneus) in Selva de Florencia National Park, Colombia. Neotropical Primates 19:46-47.

Roncancio-Duque, N., and L. A. Vélez Vanegas. 2019. Valores objeto de conservación del subsistema de áreas protegidas de los Andes occidentales, Colombia. Revista de la Academia Colombiana de Ciencias Exactas, Físicas y Naturales 43:52-64.

Simmons, N. B., AND R. S. Voss. 1998. The mammals of Paracou, French Guiana, a Neotropical lowland rainforest fauna. Part 1 , Bats. Bulletin of the American Museum of Natural History 237:1-219.

Soları, S., Y. Muñoz-Saba, J. V. Rodríguez-Mahecha, T. R. Defler, H. E. Ramírez-Chaves, and F. Trujillo. 2013. Riqueza, endemismo y conservación de los mamíferos de Colombia. Mastozoología Neotropical 20:301-365.

Suárez-Castro, A. F., and H. E. Ramírez-Chaves (eds.). 2015. Los carnívoros terrestres y semiacuáticos continentales de Colombia. Guía de Campo. Bogotá: Editorial Universidad Nacional de Colombia, Bogotá, Colombia.

Voss, R. S., AND L. H. Emmons. 1996. Mammalian diversity in Neotropical lowland rainforests: a preliminary assessment. Bulletin of the American Museum of Natural History 230:1-115.

Voss, R. S., D. Lunde, ANd N. B. Simmons. 2001. The mammals of Paracou, French Guiana: a Neotropical lowland rainforest fauna part 2. Nonvolant species. Bulletin of the American Museum of Natural History 263:3-236.
Voss, R. S., C. Hubbard, and S. A. Jansa. 2013. Phylogenetic relationships of New World porcupines (Rodentia, Erethizontidae): implications for taxonomy, morphological evolution, and biogeography. American Museum Novitates 3769:1-36.

Voss, R. S., J. F. Díaz-Nieto, ANd S. A. Jansa. 2018. A revision of Philander (Marsupialia: Didelphidae), Part 1: P. quica, P. canus, and a new species from Amazonia. American Museum Novitates 3891:1-70.

Voss, R.S., T. C. Giarla, J. F. Díaz-Nieto, and S. A. Jansa. 2020. A revision of the didelphid marsupial genus Marmosa. Part 2. Species of the Rapposa Group (subgenus Micoureus). Bulletin of the American Museum of Natural History 439:1-60.

Associated editor: Sergio Solari

Submitted: November 22, 2020; Reviewed: February 15, 2021

Accepted:March 20, 2021; Published on line: April 19, 2021. 


\section{Appendix 1}

Cranial and external measurements (in $\mathrm{mm}$ ) of the mammals registered in the Selva de Florencia National Natural Park (see materials and methods for the acronyms of the measures we take). M: male; F: female

\section{Didelphimorphia:}

Marmosa regina/isthmica (MHN-UCa 1612 M Ad): HBL: 410; LT: 220; HF: 27; LE: 32; Wt: 159; CBL: 44.95; MTR: 17.07; LM: 8.50; PB: 14.32; PL: 24.93; NB: 5.52; LIB: 7.93; LPB: 6.74; ZB: 25.20.

Marmosa sp. (MHN-UCa 876 M Ad): HBL: 462; LT: 255; HF: 25.25; LE: 20.17; Wt: -; CBL: 47.89; MTR: 18.67; LM: 9.13; PB: 12.29; PL: 25.41; NB: 6.85; LIB: 8.7; LPB: 7.48; ZB: 26.81.

Philander melanurus (MHN-UCa 1614 M Ad): HBL: 600; LT: 300; HF: 50; LE: 33; Wt: -; CBL: 71.24; MTR: 29.95; LM: 14.18; PB: 21.51; PL: 42.18; NB: 9.66; LIB: 13.86; LPB: 9.53; ZB: 38.90.

Didelphis marsupialis (MHN-UCa 208 juvenile): HBL: -; LT: -; HF: -; LE: -; Wt: -; CBL: 85.12; MTR: 35.31; LM: 14.93; PB: 26.98; PL: 52.12; NB: 13.46; LIB: 17.53; LPB: 11.40; ZB: 45.77.

Monodelphis adusta (MHN-UCa 263 F Ad): HBL: 100; LT: 37; HF: 12; LE: 10; Wt: 6; CBL: -; MTR: -; LM: -; PB: -; PL: -; NB: -; LIB: -; LPB: -; ZB: -.

Metachirus myosuros (MHN-UCa 1613M Ad): HBL: 617; LT: 315; HF: 47; LE: 35; Wt: 307; CBL: 59.77; MTR: 24.31; LM: 11.75; PB: 15.42; PL: 32.55; NB: 10.13; LIB: 13.74; LPB: 9.85; ZB: 31.91.

\section{Chiroptera:}

Artibeus anderseni (MHN-UCa 1641M): HBL: 45; LT: 0; HF: 8.8; LE: 15.5; FL: 37.6; Wt: 10; GLS: 18.39; CIL: 16.5; CCL: 15.89; LB: 6.05; PB: 4.05; ZB: 10.83; BB: 8.32; MB: 9.53; MTR: 5.9; BM-M: 7.91; BC-C: 5.18.

Artibeus glaucus (MHN-UCa 0172F): HBL: 57; LT: 0; HF: 9; LE: 16; FL: 40; Wt: 15; GLS: 20.08; CIL: 18.07; CCL: 17.31; LB: 5.58; PB: 4.71; ZB: 11.52; BB: 8.89; MB: 10.45; MTR: 6.55; BM-M: 8.18; BC-C: 5.55.

Artibeus bogotensis (MHN-UCa 1642 F): HBL: 52; LT: 0; HF: 7.4; LE: 16.5; FL: 41.8; Wt: 17.5; GLS: 20.69; CIL: 19.93; CCL: 18.16; LB: 6.13; PB: 5.28; ZB: 12.02; BB: 9.28; MB: 10.75; MTR: 6.86; BM-M: 8.74; BC-C: 5.45

Eptesicus andinus (MHN-UCa 0914 F): HBL: 112; LT: 47.3; HF: 9.4; LE: 17; FL: 43.2; Wt: 10; GLS: 16.94; CIL: 16.1; CCL: 15.17; LB: 6.53; PB: 4.29; ZB: 18.82; BB: 7.99; MB: 8.46; MTR: 6.35; BM_M: 6.92; BC-C: 5.03.

Eptesicus chiriquinus (MHN-UCa 0147 F): HBL: 109; LT: 48; HF: 11.4; LE: 15.6; FL: 46.4; Wt: 14; GLS: -; CIL: -; CCL: 15.77; LB: PB: 4.31; ZB: -; BB: -; MB: 9.25; MTR: 6.93; BM_M: 7.65; BC-C: 5.29.

Myotis caucensis (MHN-UCa 0050 M): HBL: 81.7; LT: 40.2; HF: 7.3; LE: 13; FL: 37.3; Wt: 5; GLS: 14.29; CIL: 13.73; CCL: 12.79; LB: 3.88; PB: 3.72; ZB: -; BB: 6.55; MB: 7.15; MTR: 5.7; BM_M: 6.15; BC-C: 3.85 .

Myotis keasyi (MHN-UCa 1659 F): HBL: 85; LT: 38; HF: 6; LE: 12; FL: 38.9; Wt: 6; GLS: 14.01; CIL: 13.47; CCL: 12.62; LB: 4.19; PB: 3.64; ZB: 9.23; BB: 6.51; MB: 7.26; MTR: 5.43; BM_M: 5.69; BC-C: 3.72.

Myotis riparius (MHN-UCa 1658 F): HBL: 83; LT: 38; HF: 8; LE: 15; FL: 36; Wt: 5; GLS: 13.49; CIL: 13.17; CCL: 12.03; LB: 3.92; PB: 3.62; ZB: 8.62; BB: 6.97; MB: 7.03; MTR: 5.13; BM_M: 5.75; BC-C: 3.83. (MHN-UCa 1657 M): HBL: 84; LT: 43; HF: 6.8; LE: 14; FL: 39.1;Wt: 6; GLS: 13.98; CIL: 13.76; CCL: 12.61; LB: 3.53; PB: 3.36; ZB: 8.61; BB: 6.33; MB: 7.03; MTR: 6.16; BM_M: 5.79; BC-C: 3.81.

\section{Carnivora:}

Cerdocyon thous (MHN-UCa 200): CBL: 126.13; BB: 45.33; LIB: 24.14; LPB: 32.15; BR: 20.69; ZB: 69.4.

Leopardus tigrinus (MHN-UCa 205): CBL: 85.24; BB: 37.56; LIB: 15.5; LPB: 23.15; BR: 19.99; ZB: 51.6.

Bassaricyon neblina (MHN-UCa 1631 F): CBL: 74.39; BB: 34.68; LIB: 15.93; LPB: 17.4; BR: 16.1; ZB: 46.05.

Rodentia: Values are the observed range (in parentheses) and the mean.

Handleyomys alfaroi ( $n=2 \mathrm{M}$ ): HBL: (212-244) 228; LT: (106-127) 116.5; HF: (25-28) 26.5; LE: 17 -; CIL: (23.14-26.7) 24.92; LD: (6.43-7.82) 7.13; LM: (3.58-4.1) 3.84; BM1: (1.15-1.24) 1.195; LIF: (4.56-5.18) 4.87; BIF: (2.08-2.72) 2.4; PB: (2.61-3.48) 3.05; BZP: (2.65-3.09) 2.87; ZB: (12.74-15.39) 14.07; LIB: (4.8-5.43) 5.12; NL: (10.39-11.62) 11.01; IPB: (10.63-11.25) 10.94.

Handleyomys alfaroi ( $n=5$ F): HBL: (215-230) 220.6; LT: (105-119) 111; HF: (25-28) 26; LE: (16-18) 17; CIL: (23.03-25.12) 24.26; LD: (6.26-7.09) 6.7; LM: (3.74-3.87) 3.83; BM1: (1.07-1.19) 1.15; LIF: (4.18-4.9) 4.5; BIF: (2.13-2.39) 2.29; PB: (2.71-2.93) 2.81; BZP: (2.66-3.07) 2.86; ZB: (13.14-13.69) 13.46; LIB: (4.9-5.53) 5.12; NL: (10.73-11.78) 11.16; IPB: (10.48-11.11) 10.92.

Transandinomys talamancae ( $\mathrm{n}=2 \mathrm{M})$ : HBL: (184-264) 224; LT: (94-127) 110.5; HF: (26-29) 27.5; LE: 17; CIL: 23.18; LD: (6.378.27) 7.32; LM: (4.49-4.58) 4.535; BM1: 1.33; LIF: (3.49-4.43) 3.96; BIF: (1.83-1.88) 1.855; PB: (2.5-3.14) 2.82; BZP: (2.58-3.43) 3.01; ZB: 13.26; LIB: (5.08-5.34) 5.21; NL: (10.01-11.99) 11; IPB: 11.12.

Melanomys caliginosus ( $\mathrm{n}=4$ F): HBL: (197-243) 217.5; LT: (85-108) 93.75; HF: (26-28) 27; LE: (16-15) 15.75; CIL: (24.5128.02) 26.27; LD: (6.41-7.62) 7.095; LM: (3.97-4.81) 4.6; BM1: (1.18-1.51) 1.36; LIF: (3.85-4.6) 4.375; BIF: (1.78-2.25) 1.97; PB: (2.87-3.21) 3.01; BZP: (2.55-3.12) 2.86; ZB: (13.68-16.14) 15.25; LIB: (4.82-6.23) 5.74; NL: (10.2- 12.12) 11.56; IPB: (11.48-12) 
21.77. ( $n=3$ M): HBL: (200-216) 206.6; LT: (85-95) 88.67; HF: (26-27) 26.33; LE: (15-16) 15.67; CIL: (24.23-27.44) 25.93; LD: (6.39-7.46) 6.926; LM: (4.52-4.77) 4.58; BM1: (1.39-1.44) 1.41; LIF: (3.5-4.68) 4.26; BIF: (1.63-1.83) 1.74; PB: (2.5-2.87) 2.65; BZP: (2.31-2.83) 2.65; ZB: (14.57-15.78) 15.19; LIB: (5.93-6.12) 6.02; NL: (10.70-10.74) 10.60; IPB: (11.61-12.1) 11.87.

Tylomys mirae (FMNH 71215 M): HBL: 477; LT: 229; HF: 40; LE: 29; CIL: 47.54; LD: 14.04; LM: 8.73; BM1: 2.23; LIF: 8.82; BIF: 3.76; PB: 4.61; BZP: 8.23; ZB: 26.14; LIB: 10.90; NL: 17.0; IPB: 17.33.

Nectomys magdalenae (MHN-UCa 1448 M): HBL: 500; LT: 242; HF: 48; LE: 15.87; CIL: 42.62; LD: 12.38; LM: 7.08; BM1: 2.13; LIF: 6.74; BIF: 3.43; PB: 4.97; BZP: 5.26; ZB: 24.57; LIB: 7.44; NL: 18.59; IPB: 8.91.

Neacomys tenuipes (MHN-UCa 1627, 1628, 1692 F) HBL: 157; LT: 85; HF: 18; LE: 14; CIL: 18.42; LD: 5.16; LM: 2.68; BM1: 0.79; LIF: 2.47; BIF: 1.62; PB: 2.41; BZP: 1.73; ZB: 10.06; LIB: 4.17; NL: 8.6; IPB: 7.79. (2n= M) HBL: (160-166.22) 163.11; LT: (8791.3) 89.15; HF: (20.3-21) 20.65; LE: 15.6; CIL: (18.17-19.58) 18.88; LD: (5.2-5.89) 5.545; LM: (2.268-2.85) 2.56; BM1: (0.91-0.92) 0.92; LIF: (2.41-2.47) 2.44; BIF: (1.61-1.48) 1.55; PB: (2.34-2.63) 2.49; BZP: (1.68-1.86) 1.77; ZB: 11.33; LIB: (4.26-4.41) 4.36; NL: (8.7-8.87) 8.79; IPB: (8.03-8.37) 8.20.

Sigmodontomys alfari (MHN_UCa 1630 M): HBL: 280; LT: 155; HF: 31; LE: 17; CIL: 31.58; LD: 9.59; LM: 5.52; BM1: 1.85; LIF: 4.9; BIF: 2.32; PB: 3.09; BZP: 4.23; ZB: 17.64; LIB: 6; NL: 14.43; IPB: 7.73.

Heteromys aff. anomalus ( $n=4 \mathrm{M})$ : HBL: (196-265) 232.25; LT: (110-145) 132.50; HF: (28.6-33) 30.20; LE: (13.5-19) 16.13; CIL: (23.25-29.02) 26.59; LD: (7.11-9.06) 8.18; LM: (4.08-5.07) 4.71; BM1: (1.4-1.72) 1.52; LIF: (1.6-1.9) 1.76; BIF: (0.91-0.95) 0.93; PB: (1.67-2.62) 2.18; BZP: (3.29-3.72) 3.45; ZB: (15.13-16.79) 15.86; LIB: (7.27-9.07) 8.47; NL: (12.65-13.97) 13.29; IPB: (7.638.49) 8.12. (F): HBL: 242; LT: 147; HF: 33.1; LE: 17; CIL: 27.66; LD: 8.45; LM: 4.69; BM1: 1.59; LIF: 1.63; BIF: 0.93; PB: 2.61; BZP: 3.46; ZB: 15.02; LIB: 8.96; NL: 13.52; IPB: 7.75.

Nephelomys pectoralis (MHN-UCa 185 F, 190 F): HBL: (300-335) 317.5; LT: (162-190) 117.6; HF: (34.3-36.7) 35.5; LE: (2122.4) 21.7; CIL: (32.65-35.53) 34.09; LD: (9.78-10.48) 10.13; LM: (5.29-5.84) 5.57; BM1: (1.63-1.67) 1.65; LIF: (6.27-6.77) 6.52; BIF: (2.97-2.98) 2.98; PB: (3.82-3.85) 3.84; BZP: (3.87-3.96) 3.92; ZB: (17.22-19.63) 18.43; LIB: (4.97-5.36) 5.17; NL: (13.25-14.64) 13.95; IPB: (9.4-10.78) 10.09. (MHN-UCa 188 M): HBL: 300; LT: 160; HF: 33.1; LE: 21.1; CIL: 31.01; LD: 9.12; LM: 5.54; BM1: 1.57; LIF: 6.4; BIF: 2.99; PB: 3.69; BZP: 3.77; ZB: 17.12; LIB: 5; NL: 11.94; IPB: 9.25.

Nephelomys childi (MHN-UCa 772 M): HBL: 290.7; LT: 140; HF: 33.45; LE: 21.95; CIL: 31.49; LD: 9.44; LM: 5.33; BM1: 1.51; LIF: 5.37; BIF: 2.56; PB: 3.71; BZP: 3.7; ZB: 17.27; LIB: 5.57; NL: 12.29; IPB: 9.61. 
476 THERYA Vol. 12 (3): 461-475 